\title{
Brief Discussion on the Quality of Secretarial Clerk of Party and Government Offices in Vocational Colleges
}

\author{
Shengxuan Zhang \\ Guangdong Mechanical and Electrical, Guangdong, Guangzhou, 510515, China
}

Keywords: Vocational colleges, Party and government offices, Secretarial clerk, Quality

\begin{abstract}
Party and government offices in vocational colleges is the core organization for colleges' party affairs construction and plays a decisive role in dealing with colleges' administrative affairs and coordinating each institution' $s$ work as well as archive file management. Therefore, the comprehensive quality of secretarial clerk of party and government offices has an important impact on vocational colleges' party affairs construction. To make party and government offices better in serving campus and effective in dealing with all kinds of affairs in campus, the quality education of secretarial clerk of party and government offices must be enhanced so as to develop their professional quality and improve their working ability. How to comprehensively improve the quality of secretarial clerk of party and government offices in vocational colleges is the priority in colleges' party and government construction at current stage. This paper combines the work characteristics of party and government offices in vocational colleges, analyzes the professional quality that office secretarial clerk should have and proposes the specific methods for improving the quality of secretarial clerk so as to provide some references and suggestions for the party and government construction in vocational colleges.
\end{abstract}

\section{Introduction}

Party and government office in vocational colleges is the administrative body under the leadership of college party committee. It mainly serves for scientific research project and teaching activity in college and acts as an advisor and assistant to college authority. Its major responsibility is comprehensively dealing with administrative affairs in college, coordinating the relations between each department, setting out college' s development plan and handling and recording each documents and so $\mathrm{on}^{[1]}$. In recent years, with the deepening of our country' s education system reform, the function of party and government office in vocational colleges is also gradually becoming obvious. If the secretarial clerk of the office do not have a strong professional ability and professional quality, it is difficult for them to make proper communication with the service objects so that they are incompetent for this job. Therefore, the office has a higher requirement for the comprehensive quality of secretarial clerk. The secretarial clerk in party and government office of vocational colleges not only need to be familiar with office working procedure and work content, but also need to improve their own comprehensive quality and practice ability and have higher political and moral quality, professional ability quality, cultural quality and mental quality. On in this way can they be more competent to act as office secretary so as to serve for the general situation of college development in a reasonable and effective manner.

\section{The work characteristics of party and government office in vocational colleges}

The work in party and government office is comprehensive.

The status of party and government office in the vocational colleges determines that its working content is comprehensive. Party and government office is the hub of school running. And it is closely linked with departments at all levels in schools, leaders at all levels and all employees are closely linked and serve to enhance the quality of teaching, fulfill research tasks and achieve administrative management and other matters ${ }^{[2]}$. Meanwhile, a party and government office has close relationship with after-school activities. Its role is to communicate with other institutions and coordinate their 
relations. Specifically, its work includes drafting and printing documents, records management, receiving visitors, collecting information, organizing meetings and etc. The work is strongly comprehensive, which requires the office can handle the overall situation and ensure that the affairs of the campus is organized and coordinated and operated normally. In addition, from the nature of the party and government office, it not only provides information to relevant departments, participate in management decisions, rules of procedure and other activities, but also deal with the administrative affairs of the offices within the school. These factors determine the comprehensive features of party and government office work ${ }^{[3]}$.

\section{The work in party and government office is coordinative.}

The overall size of vocational colleges is relatively large and is relatively complex regarding internal levels. In order to ensure the school work is orderly conducted, the coordinating role of the party and government offices is particularly important ${ }^{[4]}$. Party and government office need to ensure timely and accurate information transmission and information feedback, so that the working pace of each department in colleges is consistent and assist school leaders in coordinating each party' s relation. At the same time, various conflicts within vocational colleges also require the coordination and handling from party and government office. Only when coordination the work of the party and government offices is well done, then the conflict among the school staff and the conflict between scientific research tasks and management systems can be resolved so as to achieve mutual cooperation and common progress.

\section{The work in party and government office is service.}

The working nature of the party and government office in vocational colleges determines that it is administrative office to college leaders. First of all, the party and government office must be at publication of papers issued by leaders so as to ensure that the new policies are implemented as soon as possible in the school; secondly, the party and government office need to organize all kinds of meetings in schools and make accurate records about meeting content and participate in decision-making and discussion in the meeting and finally, it also need to make practical recommendations and work programs for school construction, provide timely and accurate information to the leadership and ensure that school leaders to make the right decisions. In addition, the clerical staff of party and government office need to timely complete each work assigned by college leader and provide quality services for the campus departments and agencies.

\section{The work in party and government office is confidential.}

The work of party and government office in vocational colleges is highly confidential, mainly reflected in two aspects: first, the work of the party and government office is a direct service to school leaders, so various archives, documentation and data managed by office clerical personnel is closely linked with school leaders including participation in meetings, activities arrangements and other specific matters, which involve the secrets of party and state that should not be open ${ }^{[5]}$; secondly, the work matters mastered by government office clerical staff is long-term, critical, and overall, which also emphasizes the importance and significance of working nature of the party and government office.

\section{The requirement of party and government office in vocational colleges for secretarial clerk}

\section{Ideological and political quality.}

Fundamentally, the ideological and political quality is the basic requirement for the whole public. The secretary personnel in Party and government's office of higher vocational colleges have the feature of serving for teaching activities and $\mathrm{R} \& \mathrm{~S}$ projects directly. Thus there are higher requirement of their ideological and political quality. Firstly, they should have correct political direction and good consciousness, in their work they need to implement the ideology of "three representative" adhering to the Party' s ideological route to implement the Party' s policy and guidelines ${ }^{[6]}$; Secondly, the secretary personnel should be hardworking and earnest with strong sense of career and responsibility. They must be careful and responsible and keep a modest and cautious working attitude. 


\section{Professional ability quality.}

The secretarial work of party and government office in higher vocational colleges is strongly comprehensive and has rather requirements on capacity of office equipment operation and so on. Strong theoretical foundation is the basis for office clerical staff including the administration management, archives, secretary writing and other professional knowledge. In terms of expertise, advice is the ability that party and government office clerical staff must have. Clerical staff must provide timely information to help school leadership for their decision-making and provide a reasonable reference for the construction and development of the school. Information processing includes information collection, collation, analysis, classification, processing, screening and other processes. Providing information timely to leaders can help them make the right decisions on school matters and achieve scientific management. Ability to operate office equipment is an important indicator to evaluate the quality level of the party and government office clerical staff. As in data collection, drafting files, file archiving and documentation search, if the secretarial staff is able to skillfully use modern technologies for processing, it will greatly shorten the working time and improve efficiency. In addition, secretarial staff in their daily work in the office is also responsible for receiving files and visitors and other work. Only if secretarial staff have a high quality of service capabilities, then they can do well in the each work of party and government office so as to ensure highly efficient and orderly running of office work.

\section{Mental quality.}

Secretary of the party and government offices often need to regularly contact with the leadership of the school at all levels, which is the advantages of secretarial staff. However, as higher party and government office is the central department in vocational colleges, so the task is arduous, the content is complex, working pressure is high, which requires that the party and government office secretarial staff must have a high mental quality and always maintain a good attitude and have the hard-working spirit and indomitable will, have the courage to accept criticism, and withstood got wronged. Only in this way can they maintain their enthusiasm for secretarial work and maintain the normal operation of the party and government office daily work.

\section{Social communication quality.}

Social communication is one of the important works of the party and government office in vocational colleges. Party and government office is the "window" of higher vocational colleges, whether on campus or off-campus exchanges and services. The party and government office clerical staff should have a certain degree of social communication, in the exchanging process, they should be adept at communication methods, to be so soft in mood, and to be neither humble nor pushy and have a distinctive attitude, graceful ${ }^{[7]}$. Social communication quality of party and government office in vocational colleges secretarial staff is also reflected in the relationship with their superiors and the school staff. Whether the relationship between workers and clerical staff and school leadership is in harmony can accurately reflect the secretary' s interpersonal processing capability. To coordinate the relationship between employees at all levels of school well, first it requires that the office clerical staff have strong social skills. Only when the complex interpersonal relationship is dealt with well in schools, it can ensure school' s health flourish and development.

\section{Innovation quality.}

Innovation quality of the party and government office clerical staff in vocational colleges is also one important quality for work, as vocational colleges are at the forefront of the times. Secretarial staff can only improve their professional level through continuous innovation. Especially secretarial work at the party and government office, it needs to constantly adapt to the demand of superiors for secretarial work, develop their own ability to analyze and solve problems, increase their knowledge in practice, give full play to their own the enthusiasm and creativity on the basis of organizing material, drafting documents, at the same time secretarial staff should motivate themselves to struggle forward so that carry out secretarial work with plan and purpose according to their actual situation. 
The specific measurement for improving the quality of secretarial clerk of party and government office

\section{skill. \\ Increase the intensity of learning and develop secretarial clerk's expression and writing}

The work characteristics of party and government office in vocational colleges requires require that secretarial staff should have a strong operational capacity and relatively wide range of professional knowledge, therefore, party and government office clerical staff can only improve themselves through continuous learning to in order to adapt to the requirement of contemporary vocational colleges party and government office for secretarial work. Secretarial staff needs to recognize that the nature of their work is not just these basic elements such as collating information, writing material. They need think problems ideologically from leadership point of view and help leaders to gather information analyze problems and propose solutions. Therefore, party and government office clerical staff need to constantly enrich their knowledge base, expand their knowledge, and actively study the party's principles and policies, and grasp the contents of the documents so as to make themselves more competitive in the party and government office work.

The unity of knowledge and practice, comprehensively improve the professional practice ability of secretarial staff.

Party and government office secretarial work has the characteristics of being "numerous, complex, tight, heavy", which also determines the secretarial staff lack adequate time to study and receive training in professional training institutions and they only can enrich their knowledge through the office work ${ }^{[8]}$. Thus, office clerical staff needs to regard the work as a classroom to enhance their professional capabilities and cherish every practice opportunity at work. Only through continuous accumulation and practice can they master the rules of office work so as to make great contribution to improve their overall quality and operational capabilities. In addition, the nature of secretarial work is special, it requires not only practitioners have the appropriate practical ability, meanwhile it has rather high requirement for the theoretical knowledge. Only under the guidance of the theory of knowledge, the practical operation can be guaranteed to be accurate and efficient. Therefore, secretarial staff needs to strengthen theory knowledge study at work and keep improving professional quality so as to better serve the party and government offices and schools.

Attach great importance to communication skills and enhance training for secretarial personnel.

Professional training for secretarial staff must highlight the principle of "teaching based on needs, applying knowledge into practice". The training content should be made properly according to the actual situation of operational capacity, service year of secretarial personnel develop so that all office clerical staff can be further enhanced on their original basis. Specific forms of training can be flexible, for example you can set up professional training class for collective learning. On the one hand it save costs, on the other hand it can also promote mutual exchange and study between colleagues. The training process can also ask for professional' s counseling, who can train secretarial clerk with their wealth of practical experience and a solid theoretical foundation, meanwhile arrange secretarial staff to study by themselves and evaluation about study situation at different stages with limited time so as to know the training effect.

\section{Summary}

In summary, vocational colleges attaches great importance to train the comprehensive quality of secretarial clerk of party and government office. Only continue to improve business literacy Party and government office clerical staff, when the professional quality of secretarial clerk of party and government office keep improving and their service consciousness and innovation awareness is enhance, they can effectively assist colleges' management activities, improve the working efficiency of party and government office so as to promote the better development of vocational colleges. 


\section{References}

[1] Xu Tiannan. Analysis on the quality of secretarial clerk of college office. Modern Business Trade Industry,2011,23(3):138-139.

[2] Zhang Maoye. The necessary capabilities and qualities of secretarial clerk in party and government authority. Office Operation2014 (18):15-15.

[3] Wang Junhong Study on the work characteristics of college office and the improvement of secretarial clerk quality under new situation. Economic Research Guide,2012(1):315-316.

[4] Ma Dong. Brief analysis on the quality of college secretarial clerk and documentary archives management. East West South West. Education observation,2011(4):36-37.

[5] Li Guangdong, Liu Yingying. My opinion on documentation management and the quality of office secretarial clerk. Science and Wealth,2013(10):120-120,121.

[6] Chen Junxiong. Analysis on the quality of secretarial clerk in party and government authority. Office Operation,2013(15):9

[7] Zhong Yali Brief analysis on the necessary quality of college administrative staff at primary levelon the example of college-level office secretarial clerk indoor staff. The Guide of Science \& Education,2013(5):220-221

[8] Wang Huiyang. Brief analysis on how to improve the personality charm and working ability of office secretary. Shen Zhou,2013(11):282-282. 